\title{
MOBILITAS SIRKULER DI DESA SEA SATU KECAMATAN PINELENG KABUPATEN MINAHASA
}

\author{
Simon Samuel A. Wales \\ Agnes E. Loho \\ Jean F. J. Timban
}

\begin{abstract}
This study aims to determine the circular mobility that occurs in the Sea Satu Village, Pineleng Subdistrict of Minahasa Regency, based on several aspects. The data needed to answer for the objectives is primary data and secondary data. Data were collected from direct interviews with respondents, as well as other data taken directly at the Village Head Office. The data were analyzed descriptively and described based on aspects related to circular mobility in this Sea Satu Village. The characteristics of circular mobility practitioners in Sea Satu Village, are due to aspects of age, gender, number of family members, education level, occupation type (TNI/POLRI), civil servant, private employee, entrepreneur, Honorer, Craftman, Driver and Ojek), the number of dependents. The incentive factors are the types of transportation, mileage, and the towing factors are the status of home ownership, and the cost of living.*.jnkd.
\end{abstract}

Keywords: circular mobility, Sea Satu Village, Pineleng Sub-district, Minahasa Regency

\begin{abstract}
ABSTRAK
Penelitian ini bertujuan untuk mengetahui mobilitas sirkuler yang terjadi di Desa Sea Satu Kecamatan Pineleng Kabupaten Minahasa, berdasarkan beberapa aspek. Data yang dibutuhkan untuk menjawab tujuan adalah data primer dan data sekunder. Data dikumpulkan dari wawancara langsung dengan responden, serta data lainnya diambil langsung di Kantor Kepala Desa. Data kemudian dianalisis secara deskriptif dan dijelaskan berdasarkan aspek-aspek yang terkait dengan mobilitas sirkuler di Desa Sea Satu ini. Hasil penelitian menunjukkan bahwa karakteristik dari pelaku mobilitas sirkuler di Desa Sea Satu ini terjadi karena aspek umur, jenis kelamin, jumlah anggota keluarga, tingkat pendidikan, jenis pekerjaan (TNI/POLRI), PNS, Pegawai Swasta, Wiraswasta, Honorer, Tukang, Sopir/Ojek), jumlah pendapatan, jumlah tanggungan. Faktor pendorong dari penelitian ini adalah jenis transportasi, jarak tempuh, dan faktor penarik dari penelitian ini adalah status kepemilikan rumah, dan biaya hidup. *jnkd*.
\end{abstract}

Kata kunci: mobilitas sirkuler, Desa Sea Satu, Kecamatan Pineleng, Kabupaten Minahasa.

\section{PENDAHULUAN}

\section{Latar Belakang}

Kehidupan manusia dianggap baik bila memiliki keluarga yang bahagia, pendapatan yang tetap, memiliki ilmu pengetahuan yang tinggi, transportasi yang memadai, memiliki komunikasi antar sesama dengan baik, dan banyak hal lain yang di inginkan manusia agar dapat dikatakan memiliki kehidupan yang baik. Kualitas hidup yang baik adalah suatu hal yang di inginkan manusia untuk menjalani kehidupan sehari-hari dengan rasa puas. Kebanyakan dari manusia mencari sesuatu yang mudah dicapai dan tidak sulit untuk dikerjakan, sedangkan untuk mencapai hal tersebut perlu adanya perjuangan yang lebih agar seluruh kebutuhan dapat terpenuhi, baik secara individu atau seorang diri, maupun kelompok. Kebutuhan ini dapat dipenuhi oleh masing-masing individu jika memiliki pendapatan. Pendapatan yang dihasilkan oleh seorang individu lebih mudah dikelola bila tidak mempunyai tanggung jawab lebih, sedangkan pendapatan anggota dalam rumah tangga menjadi sumber yang harus dikelola sesuai dengan kebutuhan yang diperlukan. 
Indonesia adalah negara berkembang yang memiliki perekonomian yang kuat, serta sumber daya alam dan sumber daya manusia yang terus dikembangkan. Berbagai macam sumber daya, baik sumber daya alam maupun sumber daya manusia di Indonesia dikelola dan dibentuk sesuai dengan kebutuhan masingmasing daerah, sehingga masyarakat Indonesia memanfaatkan keunggulan ini untuk meningkatkan kualitas hidup yang baik. Sulawesi Utara salah satu dari berbagai macam propinsi di Indonesia, dan Kota Manado adalah kota yang terletak di sebelah utara pulau Sulawesi sekaligus sebagai Ibukota dari Propinsi Sulawesi Utara. Kota ini termasuk kota yang terus dikembangkan oleh pemerintah, para penduduk yang tinggal di daerah ini, maupun wilayah sekitarnya. Wilayah di sekitar Manado juga sedang berkembang, dan mereka juga melihat bagaimana kota Manado berkembang serta mengadopsi cara kota ini untuk terus berkembang. Dimulai dari pertumbuhan ekonomi, pendidikan, pembangunan wilayah, serta kebutuhan lain untuk mendukung daerah sekitarnya. Kecamatan Pineleng Kabupaten Minahasa merupakan salah satu wilayah yang sedang berkembang, baik di perekonomian, pendidikan dan juga pembangunan wilayah.

Wilayah ini memiliki penduduk yang berasal dari berbagai macam daerah di Sulawesi Utara. Menurut Pineleng Dalam Angka (2017), Kecamatan Pineleng yang terdiri dari 14 desa ini memiliki luas wilayah $49,33 \mathrm{~km}^{2}$, dengan kepadatan penduduk $617 \mathrm{jiwa} / \mathrm{km}^{2}$, dan jumlah seluruh penduduk di Kecamatan Pineleng adalah 30.040 jiwa.

Desa Sea Satu adalah salah satu dari desa di Kecamatan Pineleng yang memiliki wilayah yang cukup tenang. Keluarga yang tinggal di daerah ini pada dasarnya memiliki beberapa aspek seperti lingkungan hidup yang nyaman, bisa mendapatkan biaya hidup yang rendah, dan aspek lainnya. Jarak yang dekat dengan Kota Manado serta transportasi yang sedang berkembang, mendukung penduduk di Desa Sea Satu ini untuk tinggal tetap. Desa Sea Satu yang terletak antara Desa Sea Induk dan Desa Sea Dua ini memiliki berbagai macam kebutuhan, baik secara individu maupun secara kelompok atau keluarga. Hal tersebut memacu masyarakat untuk mendapatkan pendapatan yang tinggi, menambah ilmu pengetahuan, serta faktor pendorong lainnya agar tercapai kebutuhan masing-masing individu, untuk itu penduduk melakukan perpindahan (mobilitas) dari daerah yang mempunyai pertumbuhan lambat ke daerah yang memiliki pertumbuhan yang cepat, untuk memperbaiki kualitas hidupnya (Nurman, 2015). Mobilitas adalah perpindahan penduduk dari suatu daerah ke daerah lain dengan memiliki suatu tujuan tertentu sesuai dengan kebutuhan masing-masing individu. Mantra (2015) mengatakan bahwa mobilitas penduduk dibedakan menjadi 2 (dua), yaitu mobilitas non permanen (sirkuler) yang berarti tidak tetap dan mobilitas permanen (migrasi) yang berarti tetap. Mobilitas non permanen atau mobilitas sirkuler dapat diartikan sebagai perpindahan penduduk dari suatu wilayah ke wilayah lain dengan tidak ada maskud untuk menetap di daerah tujuan (Handriawan, 2011), dengan berbagai macam aspek dari penduduk maka pekerja tetap melakukan mobilitas sirkuler untuk tetap tinggal di daerah asalnya.

Desa Sea Satu adalah desa dengan penduduk terbanyak yang melakukan mobilitas sirkuler. Berkaitan dengan uraian sebelumnya, maka peneliti tertarik melihat aspek yang mendukung kelancaran mobilitas sirkuler yang terjadi di Desa Sea Satu Kecamatan Pineleng, Kabupaten Minahasa.

\section{Rumusan Masalah}

Berdasarkan latar belakang di atas, maka akan diteliti tentang bagaimana mobilitas sirkuler di Desa Sea Satu Kecamatan Pineleng Kabupaten Minahasa.

\section{Tujuan Penelitian}

Tujuan dari penelitian ini adalah untuk mengkaji aspek terjadinya mobilitas sirkuler di Desa Sea Satu, Kecamatan Pineleng, Kabupaten Minahasa

\section{Manfaat Penelitian}

Penelitian ini diharapkan bermanfaat untuk memberikan informasi tentang mobilitas sirkuler yang terjadi dari Desa Sea Satu ke Kota Manado. 


\section{METODE PENELITIAN}

\section{Waktu dan Tempat}

Penelitian ini dilakukan selama 3 (tiga) bulan yaitu dari bulan Januari 2018 sampai bulan Maret 2018. Penelitian berlokasi di Desa Sea Satu Kecamatan Pineleng Kabupaten Minahasa.

\section{Metode pengambilan sampel}

Sampel yang digunakan dalam penelitian ini adalah pekerja baik formal maupun informal di Kecamatan Pineleng yang bekerja di Kota Manado. Sampel yang akan digunakan dalam penelitian ini diperoleh secara Stratified Random Sampling menurut jenis pekerjaan dan akan diperoleh pada desa yang penduduknya banyak melakukan mobilitas sirkuler.

\section{Metode pengumpulan data}

Data yang diperlukan dalam penelitian ini adalah data yang berbentuk data primer dan data sekunder. Data primer dalam penelitian ini adalah data yang akan diperoleh dengan cara wawancara langsung dengan responden berdasarkan daftar pertanyaan yang disusun dan akan di isi langsung oleh penduduk di Desa Sea Satu Kecamatan Pineleng, dimana penduduk di dalamnya memiliki banyak pekerja pelaku mobilitas sirkuler. Data sekunder diperoleh dari instansi-instansi yang terkait langsung seperti Kantor BPS, Kantor Hukum Tua Desa Sea Satu, Kantor Kecamatan Pineleng, serta dinas lain yang terkait dengan penelitian ini.

\section{Variabel Penelitian}

Variabel yang diukur dalam penelitian ini adalah variabel yang terkait dengan aspek-aspek mobilitas sirkuler di Kecamatan Pineleng dan diukur berdasarkan pergerakan penduduk yang memiliki aktifitas di Kota Manado.

Adapun pengukuran variabel adalah sebagai berikut:

1. Jumlah Penduduk menurut Mata Pencaharian tahun 2017 di Desa Sea Satu (jiwa)

2. Umur (tahun)

3. Jenis Kelamin

4. Jumlah anggota keluarga (orang)
5. Pendidikan Terakhir (SD, SMP, SMA, Diploma, Sarjana).

6. Jenis Pekerjaan (TNI/POLRI, PNS, Pegawai Swasta, Wiraswasta, Honorer, Tukang, Sopir/Ojek).

7. Pendapatan (per/Bulan).

8. Jumlah tanggungan (orang).

9. Jenis Transportasi (Mobil, Motor, Angkutan Umum/ Taxi Online).

10. Jarak Tempuh (Km).

11. Status Kepemilikan Rumah (Milik Sendiri atau Milik Orang Tua).

12. Biaya Hidup (Jumlah Pengeluaran per/Bulan dan Biaya Transportasi).

\section{Metode analisis data}

Data yang sudah ada, dikumpulkan dan disusun serta di analisis secara deskriptif.

\section{HASIL DAN PEMBAHASAN}

\section{Deskripsi Wilayah Penelitian}

Desa Sea Satu adalah suatu wilayah Desa yang terletak di Kecamatan Pineleng, Kabupaten Minahasa, Propinsi Sulawesi Utara. Terdiri dari 8 Jaga dengan batas wilayah sebelah utara adalah Kota Manado, sebelah selatan adalah Desa Sea Induk, sebelah timur adalah Desa Sea Induk, sebelah barat adalah Desa Sea Dua Desa Sea Satu yang diresmikan pada tanggal 26 Mei tahun 2002 ini memiliki luas wilayah 60,00 $\mathrm{Ha}$ dengan ketinggian 60 - 200 Meter dpl.

\section{Keadaan Penduduk}

Desa Sea Satu yang memiliki jumlah penduduk sebanyak 2028 jiwa ini terbagi dalam 547 kartu keluarga yang tercatat dalam Kantor Hukum Tua. Pada Tabel 1 berikut dijelaskan gambaran jumlah penduduk berdasarkan jenis kelamin yang ada di Desa Sea Satu Kecamatan Pineleng.

Tabel 1. Jumlah Penduduk Desa Sea Satu Menurut Jenis Kelamin

\begin{tabular}{clll}
\hline No & Jenis Kelamin & Jumlah (Jiwa) & Persentase (\%) \\
\hline 1 & Laki-laki & 1043 & 51 \\
2 & Perempuan & 985 & 49 \\
\hline \multicolumn{2}{l}{ Jumlah } & 2028 & 100 \\
\hline \multicolumn{2}{l}{ Sumber : Kantor Desa Sea Satu 2017 }
\end{tabular}


Tabel 1 menunjukkan bahwa sebaran penduduk di Desa Sea Satu memiliki total 2028 jiwa. Jumlah jenis kelamin laki-laki sebanyak 1.043 Jiwa (51\%), dan jenis kelamin perempuan berjumlah 985 Jiwa (49\%).

\section{Jumlah Penduduk berdasarkan mata pencaharian}

Desa Sea Satu memiliki pesebaran jumlah pekerjaan yang bervariasi. Pada Tabel 2 berikut ini diuraikan jumlah dan beberapa jenis pekerjaan yang dilakukan penduduk Desa Sea Satu.

\begin{tabular}{llcr}
\multicolumn{2}{l}{ Tabel 2. Jumlah Penduduk Desa Sea Satu } & Menurut & Mata \\
& Pencaharian & & Persentase (\%) \\
\hline No & Jenis Pekerjaan & Jumlah (jiwa) & 1,39 \\
\hline 1 & TNI/POLRI & 13 & 30,41 \\
2 & PNS & 284 & 34,48 \\
3 & Swasta & 322 & 6,75 \\
4 & Wiraswasta & 63 & 1,50 \\
5 & Petani & 14 & 5,89 \\
6 & Tukang & 55 & 4,82 \\
7 & Sopir/Ojek & 45 & 0,21 \\
8 & Montir & 2 & 2,25 \\
9 & Honorer & 21 & 0,75 \\
10 & Penjahit & 7 & 1,07 \\
11 & BUMN/BUMD & 10 & 1,28 \\
12 & Tokoh Agama & 12 & 6,64 \\
13 & Pensiunan & 62 & 2,57 \\
14 & Aparat Desa & 24 & 100 \\
\hline & Jumlah & 934 &
\end{tabular}

Sumber : kantor Desa Sea Satu 2017

Tabel 2 menunjukkan bahwa ada 14 jenis pekerjaan yang tersebar di Desa Sea Satu dengan jumlah pekerja sebanyak 934 jiwa. Pekerjaan paling banyak ditekuni oleh penduduk Desa Sea Satu adalah Pegawai Swasta dengan jumlah 322 orang $(34,48 \%)$, diikuti oleh Pegawai Negeri Sipil sebanyak 284 orang $(30,41 \%)$, Wiraswasta 63 orang $(6,75 \%)$, Pensiunan 62 orang $(6,64 \%)$, dan yang paling sedikit adalah Penjahit dengan jumlah 7 orang $(0,75 \%)$.

\section{Aspek Penelitian}

Aspek penelitian yang dimaksudkan adalah ciri-ciri dari masyarakat yang berada di Desa Sea Satu dan melakukan mobilitas sirkuler ke Kota Manado. Adapun aspek yang dijelaskan dalam penelitian ini adalah umur, jenis kelamin, jumlah anggota keluarga, tingkat pendidikan, jenis pekerjaan (TNI/POLRI, PNS, Pegawai Swasta, Wiraswasta, Honorer, Tukang, Sopir/Ojek), jumlah pendapatan, jumlah tanggungan, jenis transportasi, jarak tempuh, status kepemilikan rumah, dan biaya hidup.

Umur
Salah satu faktor yang menentukan produktifitas manusia adalah umur. Dalam sebuah kegiatan atau pekerjaan umur manusia memiliki peranan penting dalam proses bekerja, baik secara fisik, cara berfikir yang matang, maupun dalam proses pengambilan keputusan di dalamnya. Umumnya seseorang memiliki kemampuan bekerja secara produktif adalah pada usia muda. Produktifitas manusia berada pada umur 17 tahun sampai 60 tahun. Pada Tabel 3 berikut ini akan diperlihatkan kelompok umur responden yang tersebar di Desa Sea Satu, dan bagi empat kelompok umur yaitu kategori 21-31 tahun, kategori 32-41 tahun, kategori 4251 tahun dan kategori 51-60 tahun. Berdasarkan sampel yang diambil dari desa Sea Satu yang berjumlah 32 sampel dan terbagi dalam 4 kategori di atas, dapat dijelaskan bahwa sebaran terbanyak adalah pada kelompok 21-31 tahun dengan jumlah 12 responden (37\%), kelompok 32-41 tahun berjumlah 7 responden (22\%), kelompok 42-51 tahun dengan jumlah 6 responden (19\%), dan yang terakhir pada kelompok 52-60 tahun dengan jumlah 7 responden $(22 \%)$.

\begin{tabular}{cccr}
\multicolumn{6}{l}{ Tabel 3. Kelompok Umur Responden } & \\
\hline No & $\begin{array}{c}\text { Kelompok } \\
\text { Umur (Tahun) }\end{array}$ & Jumlah Responden & Persentase (\%) \\
\hline 1 & $21-31$ & 12 & 37 \\
2 & $32-41$ & 7 & 22 \\
3 & $42-51$ & 6 & 19 \\
4 & $52-60$ & 7 & 22 \\
\hline & Jumlah & 32 & 100 \\
\hline
\end{tabular}

Tabel 3 menunjukkan bahwa sebagian besar responden yang melakukan mobilitas sirkuler dari Desa Sea Satu ke Manado berada pada kelompok umur 21 tahun sampai dengan 31 tahun. Dapat dikatakan bahwa pada kelompok umur tersebut merupakan umur produktif, dan sebagian besar responden tersebut masih berada dalam tahap awal bekerja, maupun sudah lama bekerja. Kategori umur 21 tahun sampai 31 tahun di Desa Sea Satu adalah yang tertinggi produktifitas kerjanya, menurut sampel yang diambil bahwa sebagian besar dari sampel meiliki fisik yang kuat untuk melakukan mobilitas sirkuler di daerah lain, sehingga responden lebih memilih untuk tetap melakukan rutinitas tersebut, yaitu mobilitas sirkuler. Sebagian besar pekerja yang 
bekerja pada kisaran umur tersebut merasa bahwa mereka memiliki tanggung jawab yang besar di dalam keluarga, seperti contoh untuk biaya sekolah anak, anak yang baru lahir, dan lainnya.

\section{Jenis Kelamin (Responden)}

Jenis kelamin akan mempengaruhi tanggung jawab seseorang terhadap keluarga, seperti contoh bahwa setiap kepala keluarga memiliki tanggung jawab yang besar terhadap anggota keluarga yang ditanggung dalam sebuah keluarga. Tabel 4 menjelaskan jenis kelamin responden yang bekerja melakukan mobilitas sirkuler di Kota Manado.

Tabel 4. Jumlah dan Persentase Pelaku Mobilitas Sirkuler

\begin{tabular}{clcr}
\multicolumn{2}{c}{ menurut Jenis Kelamin } & \\
\hline No & Jenis Kelamin & Jumlah & Persentase (\%) \\
\hline 1 & Laki-Laki & 20 & 63 \\
2 & Perempuan & 12 & 37 \\
\hline & Jumlah & 32 & 100 \\
\hline
\end{tabular}

Sumber : Diolah dari Data Primer, 2018

Tabel 4 menunjukkan bahwa dari jumlah dan Persentase pelaku mobilitas menurut jenis kelamin bahwa Persentase lakilaki sebanyak 20 responden (63\%) lebih banyak melakukan pekerjaan di Kota Manado daripada perempuan yang hanya 12 responden (37\%). Menurut sampel yang sudah diambil, laki-laki adalah Persentase tertinggi yang melakukan mobilitas sirkuler, hal ini dikarenakan sebagian besar adalah kepala keluarga yang memiliki beberapa orang tanggungan yang harus dipenuhi kebutuhannya, sehingga laki-laki yang ada di Desa Sea Satu ini tetap melakukan kegiatan mobilitas sirkuler karena tanggung jawab yang ada dalam keluarga.

\section{Jumlah Anggota Keluarga}

Jumlah anggota keluarga inti dalam satu rumah terdiri dari kepala keluarga, dan beberapa orang saudara yang tinggal dalam satu tempat serta memiliki rasa saling bergantung satu sama lain, hal ini adalah faktor yang penting dalam sebuah keluarga. Tabel 5 menjelaskan sebaran menurut jumlah anggota keluarga di Desa Sea Satu yang terbagi dalam 3 kategori.

Tabel 5. Jumlah Responden Menurut Banyaknya Anggota Keluarga

\begin{tabular}{cccr}
\hline No & $\begin{array}{c}\text { Jumlah Anggota } \\
\text { (Orang) }\end{array}$ & $\begin{array}{c}\text { Jumlah } \\
\text { Responden }\end{array}$ & Persentase (\%) \\
\hline 1 & $2-3$ & 6 & 19 \\
2 & $4-5$ & 19 & 59 \\
3 & $6-7$ & 7 & 22 \\
\hline \multicolumn{4}{l}{ Sumber : Diolah dari Data Primer, 2017}
\end{tabular}

Tabel 5 menunjukkan bahwa keluarga terbanyak adalah kategori 4-5 (orang) yang berjumlah 19 orang (59\%), dan diikuti kategori 6-7 orang yaitu 7 responden (22\%), dan yang palin sedikit adalah kategori 2-3 orang yang berjumlah 6 responden (19\%). Tabel di atas dapat disimpulkan bahwa rata-rata keluarga di Desa Sea Satu memiliki jumlah anggota dalam satu rumah terbanyak adalah 4-5 orang.

Jumlah anggota keluarga dalam satu rumah mempengaruhi responden untuk melakukan aktifitas pekerjaan di Kota Manado, sehingga responden akan mempertahankan aktifitas pekerjaan tersebut untuk memenuhi setiap kebutuhan anggota keluarga dengan baik.

\section{Tingkat Pendidikan}

Pendidikan adalah hal yang sangat penting dalam keluarga, baik untuk kepentingan pribadi maupun sebagai bagian dalam proses pembangunan wilayah. Banyak upaya yang dilakukan untuk mendapatkan pendidikan yang baik agar tidaka ada masyarakat yang putus sekolah.

\begin{tabular}{clcr}
\multicolumn{2}{c}{ Tabel 6. Tingkat pendidikan } & & Persentase (\%) \\
\hline No & Pendidikan & $\begin{array}{c}\text { Jumlah } \\
\text { Responden }\end{array}$ & - \\
& Terakhir & - & 3 \\
1 & SD/Sederajat & 1 & 25 \\
2 & SMP/Sederajat & 8 & 7 \\
3 & SMA/Sederajat & 2 & 65 \\
4 & Diploma & 21 & 100 \\
5 & Sarjana & 32 &
\end{tabular}

Tabel 6 menunjukkan bahwa rata-rata paling banyak orang yang bekerja di Kota Manado adalah lulusan sarjana (S1), hal tersebut dapat dilihat pada Tabel 6, Sarjana dengan jumlah 21 responden $(65 \%)$, diikuti dengan SMA sebanyak 8 responden (25\%), Diploma 2 responden (7\%) dan 1 responden (3\%) untuk tingkat SMP, sedangkan SD tidak ada yang bekerja di Kota Manado. 
Responden memberikan jawaban dalam pengambilan sampel, bahwa dengan tingkat pendidikan yang tinggi maka mereka dapat diterima bekerja di tempat yang mereka inginkan untuk bekerja, sehingga kebanyakan responden memilih untuk menyelesaikan gelar sarjana mereka.

\section{Jenis Pekerjaan}

Jenis pekerjaan di Desa Sea Satu dianalisa berdasarkan 7 kategori, yaitu TNI/POLRI, PNS, Pegawai Swasta, Wiraswasta, Honorer, Tukang, Sopir/Ojek. Tabel 7 menunjukkan bahwa terdapat 15 orang responden $(47 \%)$ yang bekerja sebagai pegawai Swasta, diikuti oleh Pegawai Negeri Sipil dengan jumlah 10 responden (32\%), Wiraswasta dengan jumlah 2 responden $(6 \%)$, TNI/POLRI dengan 1 responden (3\%), Honorer dengan jumlah 2 responden (6\%), Tukang dengan 1 responden (3\%), dan Sopir/Ojek dengan jumlah 1 responden (3\%). jenis pekerjaan yang paling banyak dilakukan oleh penduduk Desa Sea Satu adalah pegawai swasta karena banyak penduduk desa Sea Satu yang melakukan mobilitas sirkuler dengan lulusan Sarjana (S1). Responden memberikan jawaban bahwa pada saat mereka bekerja sebagai pegawai swasta atau PNS, mereka mendapatkan gaji atau upah yang tinggi, sehingga banyak penduduk di desa Sea Satu bekerja sebagai pegawai swasta maupun PNS.

\begin{tabular}{clcr} 
Tabel 7. Jenis Pekerjaan & Persentase (\%) \\
\hline No & Jenis Pekerjaan & $\begin{array}{c}\text { Jumlah } \\
\text { Responden }\end{array}$ & 3 \\
\hline 1 & TNI/POLRI & 1 & 31 \\
2 & PNS & 10 & 47 \\
3 & Swasta & 15 & 6 \\
4 & Wiraswasta & 2 & 6 \\
5 & Honorer & 2 & 3 \\
6 & Tukang & 1 & 3 \\
7 & Sopir/Ojek & 1 & 100 \\
\hline & Jumlah & 32 &
\end{tabular}

Sumber: Diolah dari Data Primer, 2018

\section{Pendapatan}

Pendapatan adalah hasil yang diperoleh seseorang dalam melakukan aktifitas ekonomi atau bekerja, dengan tujuan untuk mendapatkan nilai uang yang digunakan untuk kebutuhan dalam rumah tangga. Pada Tabel 8 berikut ini akan diuraikan tentang pendapatan rseponden di Desa Sea Satu.

\begin{tabular}{|c|c|c|c|}
\hline No & $\begin{array}{l}\text { Pendapatan } \\
\text { (Per/bulan) }\end{array}$ & $\begin{array}{c}\text { Jumlah } \\
\text { Responden }\end{array}$ & Persentase $(\%)$ \\
\hline 1 & $<2.000 .000$ & - & - \\
\hline 2 & $2.000 .000-4.000 .000$ & 15 & 47 \\
\hline 3 & $4.000 .000-6.000 .000$ & 14 & 44 \\
\hline 4 & $>6.000 .000$ & 3 & 9 \\
\hline & Jumlah & 32 & 100 \\
\hline
\end{tabular}

Sumber : Diolah dari Data Primer, 2018

Tabel 8 menunjukkan bahwa penghasilan yang di dapat para pekerja di Desa Sea Satu yang bekerja di Kota Manado sangat beragam, dimulai dari kelompok terbanyak yaitu Rp. 2.000.000 sampai Rp. 4.000.000 dengan 15 responden (47\%), lalu diikuti dengan kelompok Rp. 4.000.000 sampai Rp. 6.000.000 dengan jumlah responden 14 (44\%), dan pendapatan di atas $\mathrm{Rp}$. 6.000 .000 ada 3 responden (9\%). Pendapatan yang diperoleh responden di Desa Sea Satu kebanyakan adalah dari jenis pekerjaan PNS dan pegawai swasta, sehingga gaji atau upah yang didapatkan adalah di atas Rp. 2.800.000. Disimpulkan dari hal tersebut bahwa gaji di atas UMP di Kota Manado paling banyak karena PNS dan pegawai swasta memegang Persentase tertinggi untuk jumlah pendapatan.

\section{Jumlah Tanggungan}

Pendapatan dan pengeluaran dalam sebuah rumah tangga dipengaruhi oleh jumlah tanggungan di dalamnya, sehingga semakin banyak jumlah tanggungan dalam sebuah rumah tangga, maka semakin besar pengeluaran yang akan dikeluarkan untuk konsumsi dan juga kebutuhan lainnya.

Tabel 9 menjelaskan bahwa, jumlah anggota keluarga yang ditanggung di Desa Sea Satu, dari tidak ada tanggungan sampai 5 orang. Angka yang sama dengan jumlah 12 responden (38\%) untuk tidak ada tanggungan dan 1 orang tanggungan, dan diikuti dengan 2 orang tanggungan diambil oleh 7 responden $(21 \%)$, dan 1 responden (3\%) dengan jumlah tanggungan 3 orang, untuk 4 dan 5 orang di desa Sea Satu ini tidak ada.

\begin{tabular}{lccc} 
Tabel 9. Jumlah Tanggungan & \\
\hline No & $\begin{array}{c}\text { Jumlah Tanggungan } \\
\text { (Orang) }\end{array}$ & $\begin{array}{c}\text { Jumlah } \\
\text { Responden }\end{array}$ & Persentase (\%) \\
\hline 1 & 0 & 12 & 38 \\
2 & 1 & 12 & 38 \\
3 & 2 & 7 & 21 \\
4 & 3 & 1 & 3 \\
5 & 4 & - & - \\
6 & 5 & - & - \\
\hline \multicolumn{5}{l}{ Sumber : Diolah dari Data Primer, 2018 } \\
\hline
\end{tabular}


Tabel 9 menunjukkan bahwa banyak responden yang tidak memiliki tanggungan maupun hanya 1 orang tanggungan, hal ini dikarenakan kebanyakan responden dalam satu rumah sudah memiliki pekerjaan masingmasing, belum menikah dan tinggal dengan orang tua atau baru menikah dan memiliki 1 anak, sehingga 1 orang yang ditanggung adalah anaknya sendiri, sedangkan istri juga memiliki pekerjaan. Jumlah tanggungan yang lebih banyak adalah orang-orang yang memiliki lebih dari 1 anak, hal tersebut memacu responden untuk mencari pendapatan lebih agar dapat memenuhi kebutuhan orang yang ditanggung dengan melakukan mobilitas ke Kota Manado.

\section{Faktor Pendorong}

Faktor pendorong adalah faktor yang mendukung pelaku mobilitas sirkuler di Desa Sea Satu, baik mendapatkan pekerjaan, pendidikan dan aktifitas lainnya dengan tujuan untuk mendapatkan yang lebih baik dari sebelumnya. Ada 2 faktor yang diambil dalam penelitian ini, yaitu jenis transportasi dan jarak tempuh. Berikut akan dijelaskan dari masingmasing faktor yang mempengaruhi pelaku mobilitas sirkuler di Desa Sea Satu Kecamatan Pineleng.

\section{Transportasi}

Transportasi adalah alat pengangkut barang, jasa dan paling penting manusia untuk berpindah dari suatu tempat ke tempat lain. Kelancaran mobilitas dipengaruhi dengan trasnportasi yang ada pada responden, serta transportasi dari daerah lain menuju Desa Sea Satu atau sebaliknya, dari Desa Sea Satu ke daerah lain. Pada Tabel 10 berikut ini akan diuraikan 3 kategori jenis transportasi yang dipakai oleh pelaku mobilitas sirkuler di Desa Sea Satu ke Kota Manado.

Tabel 10. Jenis Transportasi

\begin{tabular}{llcr}
\hline No & $\begin{array}{l}\text { Jenis } \\
\text { Transportasi }\end{array}$ & $\begin{array}{c}\text { Jumlah } \\
\text { Responden }\end{array}$ & Persentase (\%) \\
\hline 1 & Mobil & 10 & 31 \\
2 & Motor & 17 & 53 \\
3 & Angkutan & 5 & 16 \\
& Umum/Ojek & & \\
& Online & \\
\hline \multicolumn{2}{l}{ Jumlah } & 32 & 100 \\
\hline Sumber : Diolah dari Data Primer, 2018
\end{tabular}

Tabel 10 menunjukkan bahwa jenis transportasi yang digunakan responden terbanyak adalah motor yaitu 17 responden (53\%), dan diikuti oleh mobil sebanyak 10 responden (31\%), dan sisanya dengan angkutan umum atau taxi online dengan jumlah 5 responden (16\%). Penjelasan di atas menyimpulkan bahwa paling banyak dipakai untuk bekerja adalah motor. Motor digunakan para responden untuk mengurangi pengeluaran yang berlebih, dan juga kendaraan pribadi sekarang dapat dengan mudah dimiliki. Alasan lain yaitu kemacetan menjadikan motor sebagai kendaraan pribadi yang menguntungkan untuk melakukan mobilitas di Kota Manado. Responden lainya memilih memakai mobil agar dapat mengantar orang-orang yang menjadi tanggungannya, sehingga orang yang di tanggung dapat mengurangi pengeluaran. Akses angkutan umum yang ada di Desa Sea Satu sangat kurang, para responden yang memakai angkutan umum sangat sulit untuk mengakses tempat kerja mereka, dan juga dengan berkembangnya transportasi di Kota Manado taxi online menjadi pilihan pengganti angkutan umum bagi para pelaku mobilitas sirkuler di Desa Sea Satu.

\section{Jarak Tempuh}

Jarak tempuh menunujukan seberapa jauh suatu benda bergerak dan berubah posisi melalui sebuah lintasan tertentu. Jarak tempuh menentukan pengeluaran seseorang, jika jarak tempuh jauh maka pengeluaran seseorang akan lebih besar daripada jarak tempuh yang dekat. Pada Tabel 11 berikut ini dapat dilihat seberapa jauh jarak tempuh pelaku mobilitas sirkuler di Desa Sea Satu.

Tabel 11. Jarak Tempuh

\begin{tabular}{cccr}
\hline No & $\begin{array}{l}\text { Jarak Tempuh } \\
(\mathbf{K m})\end{array}$ & Responden & Persentase $(\%)$ \\
\hline 1 & $<7,1$ & 2 & 6 \\
2 & $7,2-9,0$ & 20 & 63 \\
3 & $9,1-11,0$ & 9 & 28 \\
4 & $>11,0$ & 1 & 3 \\
\hline \multicolumn{4}{c}{ Jumlah } \\
\hline Sumber D Diolah dari Data Primer, 2018
\end{tabular}

Sumber : Diolah dari Data Primer, 2018 
Sebanyak 20 orang responden (63\%) dengan jarak tempuh antara 7,2 Km sampai 9,0 $\mathrm{Km}$, dan diikuti oleh kategori jarak tempuh 9,1 $\mathrm{Km}$ sampai 11,0 Km dengan jumlah responden $9(28 \%)$, selanjutnya adalah 2 responden (6\%) yang jarak tempuhnya kurang dari $7,1 \mathrm{Km}$, dan 1 orang responden (3\%) yang jarak tempuh lebih dari 11,0 Km untuk melakukan mobilitas sirkuler. Dari penjelasan pada Tabel 11 dapat disimpulkan bahwa rata-rata pekerja menempuh jarak 8 sampai $16 \mathrm{Km}$ setiap hari, dari pergi ke tempat kerja dan pulang ke Desa Sea Satu. Hal ini tidak mempengaruhi orang untuk tinggal di sekitar wilayah Kota Manado, dengan jarak yang jauh dan memiliki kendaraan dengan pengeluaran sedikit dapat memberikan pengeluaran yang sedikit, sehingga pelaku mobilitas sirkuler di Desa Sea Satu tetap melakukan mobilitas sirkuler.

\section{Faktor Penarik}

Selain ada faktor pendorong yang menyebabkan masyarakat melakukan mobilitas sirkuler, maka ada juga faktor penarik yang menyebabkan masyarakat tetap bertahan di daerah asalnya. Ada 2 faktor yang akan dijelaskan selanjutnya, antara lain status kepemilikan rumah dan biaya hidup yang terdiri dari jumlah pengeluaran serta biaya transportasi. Kedua faktor tersebut adalah jawaban yang sebagian besar responden berikan. Berikut adalah penjelasannya.

\section{Status Kepemilikan Rumah}

Salah satu faktor pengikat mobilitas sirkuler adalah status kepemilikan rumah. Status kepemilikan rumah yang sudah menjadi milik sendiri mengikat setiap responden untuk tetap kembali ke Desa Sea Satu, meskipun jarak tempuh yang jauh ke tempat kerja.

Tabel 12 menunjukkan bahwa responden yang berjumlah $23(72 \%)$ memiliki sendiri rumah yang ada di Desa Sea Satu, dan sebanyak 9 responden (28\%) tinggal bersama dengan orang tua. Hal ini menjelaskan bahwa responden akan tetap melakukan mobilitas sirkuler dengan jarak dekat atau jauh ke tempat kerja dan kembali di Desa Sea Satu. Hal ini menjadi faktor penarik yang kuat bagi para responden yang tinggal tetap dengan orang tua karena selain mengurangi pengeluaran, alasan lainnya adalah untuk tetap terhubung dengan keluarga dan orang tua dalam satu tempat tinggal.
Tabel 12. Status Kepemilikan Rumah

\begin{tabular}{cccr}
\hline No & $\begin{array}{c}\text { Status } \\
\text { Kepemilikan }\end{array}$ & $\begin{array}{c}\text { Jumlah } \\
\text { Responden }\end{array}$ & Persentase (\%) \\
\hline 1 & Milik Sendiri & 23 & 72 \\
2 & Milik Orang Tua & 9 & 28 \\
\hline & Jumlah & 32 & 100 \\
\hline
\end{tabular}

Sumber : Diolah dari Data Primer, 2018

Tabel 12 menunjukkan bahwa, status kepemilikan rumah mempengaruhi setiap pelaku mobilitas. Responden menjelaskan bahwa kebanyakan dari mereka sudah lama tinggal di tempat tersebut, dan tidak ingin pindah, sedangkan responden dengan status kepemilikan rumah orang tua mereka menjelaskan bahwa jika mereka tinggal dengan orang tua, maka biaya hidup akan berkurang, alasan lainnya adalah beberapa responden yang di ambil belum memiliki keluarga sendiri, sehingga responden lebih memilihuntuk tetap melakukan mobilitas sirkuler ke daerah lainnya. Menurut sampel yang sudah diambil di Desa Sea Satu, status kepemilikan rumah mempengaruhi setiap pelaku mobilitas. Responden menjelaskan bahwa kebanyakan dari mereka sudah lama tinggal di tempat tersebut, dan tidak ingin pindah, sedangkan responden dengan status kepemilikan rumah orang tua mereka menjelaskan bahwa jika mereka tinggal dengan orang tua, maka biaya hidup akan berkurang, alasan lainnya adalah beberapa responden yang di ambil belum memiliki keluarga sendiri, sehingga responden lebih memilih untuk tetap melakukan mobilitas sirkuler ke daerah lainnya.

\section{Biaya Hidup}

Biaya hidup adalah biaya yang dikeluarkan dengan jumlah tertentu sesuai kebutuhan, baik individu maupun kelompok untuk dapat terus menjalani kelangsungan hidup. Biaya hidup yang akan dijelaskan dalam bentuk Tabel 13, antara lain pengeluaran setiap bulan dan biaya transportasi yang digunakan.

\begin{tabular}{cccr}
\multicolumn{6}{l}{ Tabel 13. Pengeluaran Setiap Bulan } \\
\hline No & $\begin{array}{l}\text { Pengeluaran } \\
\text { (Per/Bulan) }\end{array}$ & $\begin{array}{c}\text { Jumlah } \\
\text { Responden }\end{array}$ & Persentase (\%) \\
\hline 1 & $<2.000 .000$ & 8 & 25 \\
2 & $2.000 .000-$ & 20 & 63 \\
& 4.000 .000 & & 12 \\
3 & $4.000 .000-$ & 4 & - \\
4 & 6.000 .000 & - & 100 \\
\hline \multicolumn{5}{c}{ Sumber : Diolah dari Data Primer, 2018 }
\end{tabular}


Tabel 13 menjelaskkan bahwa, pengeluaran setiap bulan dalam satu keluarga berada di antara Rp 2.000.000 sampai Rp. 4.000.000 dengan jumlah responden sebanyak $20(63 \%)$, lalu diikuti dengan pengeluaran kurang dari Rp. 2.000.000 sebanyak 8 responden $(25 \%)$, dan sebanyak 4 responden (12\%) dengan pengeluaran antara $\mathrm{Rp}$. 4.000.000 sampai Rp. 6.000.000.

Tabel 14. Biaya Transportasi per/Bulan

\begin{tabular}{cccr} 
No & $\begin{array}{c}\text { Biaya Transportasi } \\
\text { (Rupiah) }\end{array}$ & Responden & Persentase (\%) \\
\hline 1 & $<250.000$ & 23 & 72 \\
2 & $250.000-500.000$ & 9 & 28 \\
3 & $500.000-750.000$ & - & - \\
4 & $>750.000$ & - & - \\
\hline & Jumlah & 32 & 100 \\
\hline
\end{tabular}

Sumber : Diolah dari Data Primer, 2018

Tabel 14 menunjukkan bahwa, biaya transportasi kurang dari Rp. 250.000 per/bulan berjumlah 23 responden (72\%) dengan Persentase tertinggi, dan diikuti oleh responden sebanyak 9 orang (28\%) dengan pengeluaran per/bulan antara Rp.250.000 sampai Rp. 500.000.Dari penjelasan di atas dapat disimpulkan bahwa pelaku mobilitas sirkuler di Desa Sea Satu bertahan dengan Persentase responden mengeluarkan biaya hidup per/bulan di antara Rp. 2.000.000 sampai Rp. 4.000.000, dengan Persentase biaya transportasi tertinggi kurang dari Rp. 250.000 per/bulan. Biaya hidup yang rendah sangat menguntungkan pelaku mobilitas sirkuler di Desa Sea Satu, dengan menekan biaya hidup maka kebutuhan lain dapat dipenuhi. Pengeluaran dari setiap keluarga memberikan dampak bagi pendapatan yang ada, kebutuhan sandang dan pangan setiap hari, membayar uang sekolah anak, membayar kredit dan jasa setiap bulannya dapat ditekan untuk mendapatkan biaya hidup yang rendah, dan apabila kebutuhan masyarakat semakin besar, maka pelaku mobilitas memilih untuk bermobilitas ke Kota Manado atau daerah lain dengan tujuan untuk mendapatkan pekerjaan yang memberikan gaji yang lebih besar.

\section{KESIMPULAN DAN SARAN}

\section{Kesimpulan}

1. Karakteristik pelaku mobilitas sirkuler yang diteliti berumur antara 21-31 tahun sebesar $37 \%$, dengan jenis kelamin lakilaki sebesar 63\%. Jumlah anggota keluarga 4-5 orang sebesar 59\% dan tingkat pendidikan tertinggi lulusan sarjana (S1) dengan Persentase sebesar $65 \%$. Jenis pekerjaan pegawai swasta sebesar $47 \%$ dengan pendapatan antara Rp. 2.000.000 sampai Rp. 4.000.000.

2. Faktor pendorong terjadinya mobilitas sirkuler di Desa Sea Satu adalah jenis transportasi dengan Persentase sebesar $53 \%$, dan jarak tempuh yang dilakukan dengan Persentase sebesar 63\%.

3. Faktor penarik dari mobilitas sirkuler di Desa Sea Satu adalah status kepemilikan rumah, yaitu milik sendiri dengan Persentase sebesar $72 \%$, dan biaya hidup dengan pengeluaran setiap bulan $\mathrm{Rp}$. 2.000.000 sampai Rp. 4.000.000 dengan Persentase sebesar $63 \%$.

\section{Saran}

Pemerintah di Kabupaten Minahasa perlu berupaya lebih baik untuk mengembangkan sarana dan prasarana agar akses ke Desa Sea Satu lebih mudah, serta lebih membuka lapangan pekerjaan, agar mobilitas sirkuler berkurang dan daerah sekitar dapat berkembang.

\section{DAFTAR PUSTAKA}

Handriawan, Budi. 2011. Faktor-Faktor yang Mempengaruhi Penduduk Melakukan Mobilitas Non Permanen Menjadi Tenaga Kerja Indonesia (TKI) di Malaysia (Studi Kasus TKI Yang Pulang Di Desa Tanjungsari Kecamatan Jakenan Kabupaten Pati). Skripsi Fakultas Ekonomi. Universitas Negeri Semarang. Semarang. 
Mantra, Ida Bagoes. 2015. Demografi Umum. Nurman. 2015. Stretegi Pembangunan Pustaka Pelajar. Yogyakarta. ISBN 9799289-61-0.

Daerah. Ed 1.- Cetak 1. PT. Raja Grafindo Persada. Jakarta. ISBN 978979769- 